\title{
Effect of isoprene emissions from major forests on ozone formation in the city of Shanghai, China
}

\author{
F. Geng ${ }^{1}$, X. Tie ${ }^{2,3}$, A. Guenther ${ }^{3}$, G. $\mathbf{L i}^{4}$, J. Cao ${ }^{2}$, and P. Harley ${ }^{3}$ \\ ${ }^{1}$ Shanghai Meteorological Bureau, Shanghai, China \\ ${ }^{2}$ Institute of Earth and Environment, Chinese Academy of Science, Xi' an, China \\ ${ }^{3}$ National Center for Atmospheric Research, Boulder, CO, USA \\ ${ }^{4}$ Molina Center for Energy and the Environment, La Jolla, CA, USA
}

Received: 5 May 2011 - Published in Atmos. Chem. Phys. Discuss.: 29 June 2011

Revised: 8 September 2011 - Accepted: 7 October 2011 - Published: 20 October 2011

\begin{abstract}
Ambient surface level concentrations of isoprene $\left(\mathrm{C}_{5} \mathrm{H}_{8}\right)$ were measured in the major forest regions located south of Shanghai, China. Because there is a large coverage of broad-leaved trees in this region, high concentrations of isoprene were measured, ranging from 1 to $6 \mathrm{ppbv}$. A regional dynamical/chemical model (WRF-Chem) is applied for studying the effect of such high concentrations of isoprene on the ozone production in the city of Shanghai. The evaluation of the model shows that the calculated isoprene concentrations agree with the measured concentrations when the measured isoprene concentrations are lower than $3 \mathrm{ppb}$, but underestimate the measurements when the measured values are higher than $3 \mathrm{ppb}$. Isoprene was underestimated only at sampling sites near large bamboo plantations, a high isoprene source, indicating the need to include geospatially resolved bamboo distributions in the biogenic emission model. The assessment of the impact of isoprene on ozone formation suggests that the concentrations of peroxy radicals $\left(\mathrm{RO}_{2}\right)$ are significantly enhanced due to the oxidation of isoprene, with a maximum of 30 ppt. However, the enhancement of $\mathrm{RO}_{2}$ is confined to the forested regions. Because the concentrations of $\mathrm{NO}_{\mathrm{x}}$ were low in the forest regions, the ozone production due to the oxidation of isoprene $\left(\mathrm{C}_{5} \mathrm{H}_{8}+\mathrm{OH} \rightarrow \rightarrow \mathrm{RO}_{2}+\right.$ $\mathrm{NO} \rightarrow \rightarrow \mathrm{O}_{3}$ ) is low (less than 2-3 $\mathrm{ppb} \mathrm{h}^{-1}$ ). The calculation further suggests that the oxidation of isoprene leads to the enhancement of carbonyls (such as formaldehyde and acetaldehyde) in the regions downwind of the forests, due to continuous oxidation of isoprene in the forest air. As a result, the concentrations of $\mathrm{HO}_{2}$ radical are enhanced, resulting from the photo-disassociation of formaldehyde and acetaldehyde. Because the enhancement of $\mathrm{HO}_{2}$ radical occurs in regions
\end{abstract}

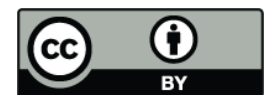

Correspondence to: $\mathrm{X}$. Tie (xxtie@ucar.edu) downwind of the forests, the enhancement of ozone production $\left(6-8 \mathrm{ppb} \mathrm{h}^{-1}\right)$ is higher than in the forest region, causing by higher anthropogenic emissions of $\mathrm{NO}_{\mathrm{x}}$. This study suggests that the biogenic emissions in the major forests to the south of Shanghai have important impacts on the levels of ozone in the city, mainly due to the carbonyls produced by the continuous oxidation of isoprene in the forest air.

\section{Introduction}

Biogenic volatile organic compounds (BVOCs) from biogenic sources have important impacts on tropospheric chemistry, such as the formation of aerosols and ozone. For example, the global emission of methanol $\left(\mathrm{CH}_{3} \mathrm{OH}\right)$, mainly from biogenic sources, has important impact on the ozone level in remote regions (Tie et al., 2003; Jacob et al., 2005). The biogenic emissions of monoterpenes $\left(\mathrm{C}_{10} \mathrm{H}_{16}\right)$ and isoprene $\left(\mathrm{C}_{5} \mathrm{H}_{8}\right)$ can lead to the formation and growth of organic aerosols in major forest areas and high industrial regions (Lack et al., 2004; Volkamer et al., 2006; Farina et al., 2010). In addition, biogenic isoprene is a highly reactive alkene; the reaction rate with $\mathrm{OH}$ radical is higher than that of most anthropogenic volatile organic compounds (AVOCs) (Carlo et al., 2004; Cai et al., 2010). Because biogenic isoprene is emitted into the troposphere in greater quantities from vegetation than any other non-methane hydrocarbon (Guenther et al., 1995), in certain regions isoprene plays a key role in the reactions that form tropospheric ozone $\left(\mathrm{O}_{3}\right)$ (Chameides et al., 1988; Fehsenfeld et al., 1992; Pierce et al., 1998).

There are several important issues regarding the effects of isoprene on tropospheric ozone formation. For example, isoprene emissions increase exponentially with rising temperatures (Guenther et al., 1995), producing higher

Published by Copernicus Publications on behalf of the European Geosciences Union. 
isoprene emissions on warmer summer days. As a result, isoprene emissions may increase in the future in those regions experiencing higher temperatures caused by climate change (Lathiere et al., 2006; Wiedinmyer et al., 2006). In addition to temperature, isoprene emissions increase with irradiance (Guenther et al., 2000), leading to highest isoprene concentrations during summer midday periods. Thus, maximum isoprene concentrations generally coincide with periods of maximum ozone photochemical production, which makes isoprene oxidation for ozone production more efficient than other VOCs such as monoterpenes stored within plants, the concentrations of which are frequently highest at night (Chameides et al., 1988). Previous studies have also shown that the effect of isoprene on ozone production is strongly dependent upon the levels of nitrogen oxides $\left(\mathrm{NO}_{\mathrm{x}}\right)$ in the troposphere ( $\mathrm{Li}$ et al., 2007). In this case, the mixing of city air plume (containing a large amount of $\mathrm{NO}_{\mathrm{x}}$ ) and biogenic air plume (containing a large amount of BVOCs) will be favorable for the enhancement of ozone production in or near large cities, causing more air pollution problems in large urban areas (Roselle, 1994). However, there is an outstanding question, which needs to be addressed in order to understand the impact of biogenic isoprene on the formation of ozone. In large forest areas, the concentrations of $\mathrm{NO}_{\mathrm{x}}$, which is required for the chemical formation of ozone (Sillman, 1995; Kleinman et al., 2000), are generally low. Because isoprene is a very reactive species, its chemical lifetime is short (about 0.5 h) (Carslaw et al., 2000). As a result, biogenic isoprene cannot be transported long distances to mix with $\mathrm{NO}_{\mathrm{x}}$ emissions from nearby cities. This leads to a specific scientific question-under what conditions will biogenic emissions from large forest areas produce significant impacts on ozone formation in nearby large cities. This particular issue will be addressed by using both the measurement data obtained in the MIRAGE-Shanghai field experiment and a state-of-the-art regional model (WRF-Chem).

In this study, the influence of biogenic isoprene on ozone formation in Shanghai, China is investigated. Shanghai is the largest city in China. During the past two decades, Shanghai has undergone a rapid increase in economic development. For example, between 1996 and 2008 the industrial gross output increased from 0.51 to 2.56 trillion RMB (about 0.37 trillion Dollars), and the number of automobiles increased from 0.47 to 2.61 million (SMSB, 2009). Accompanying the rapid economic development, the air quality has deteriorated in recent years, leading to a significant increase in the concentrations of air pollutants such as $\mathrm{NO}_{\mathrm{x}}$ and $\mathrm{O}_{3}$ in Shanghai (Geng et al., 2007; 2009). Thus, a better understanding of the characteristics of precursors of $\mathrm{O}_{3}$ becomes an important issue for studying ozone formation and for developing effective $\mathrm{O}_{3}$ control strategies in Shanghai. Previous studies suggested that $\mathrm{O}_{3}$ chemical production is limited by the concentrations of VOCs (VOC-sensitive regime) in Shanghai (Geng et al., 2010; Cai et al., 2010). Their results implied that adding biogenic VOCs (such as isoprene) could lead to the enhancement of ozone production in this region. However, a detailed study regarding the effect of biogenic isoprene emissions on ozone formation was not conducted in their studies. In Shanghai, this issue is particularly important because there are large forests, potentially significant sources of BVOC emissions, to the south of Shanghai (Tie et al., 2006). In order to study the influence of biogenic emission on ozone formation and other issues related to the air pollution in Shanghai, an extensive field measurement campaign was conducted in the Shanghai region in September, 2009. The field measurements (MIRAGEShanghai; Megacities Impact on Regional and Global Environment in Shanghai) included air pollutants mainly due to anthropogenic emissions (such as $\mathrm{O}_{3}, \mathrm{SO}_{2}, \mathrm{CO}, \mathrm{Hg}, \mathrm{NO}_{\mathrm{x}}$, VOCs, aerosols, etc), which will be described in the following section. In addition to the influence of anthropogenic emissions, the concentrations of isoprene were also measured in the large forests to the south of Shanghai during the MIRAGE-Shanghai field campaign. A regional dynamical/chemical model (WRF-Chem) is applied to address the impact of biogenic isoprene emissions on ozone formation in Shanghai. The paper is organized in the following way. We first characterize the measured isoprene concentrations in the large forests. The emissions module of the model is then evaluated by comparing these measured isoprene concentrations with isoprene concentrations predicted by the model. Finally, the model is applied to study the sensitivity of ozone production to biogenic isoprene emissions. The descriptions of measurements and the regional chemical/dynamical model (WRF-Chem) are shown in Sect. 2. Section 3 presents the analysis of the model results.

\section{Chemical model and data}

\subsection{WRF-Chem model}

The calculations presented in this study are performed using the WRF-Chem model (version-3) (Weather Research and Forecasting with Chemistry). This modeling system includes two components: a dynamical module and a chemical module. WRF, used here as the dynamical module, is a mesocale numerical weather prediction system designed to serve both for operational forecasting and atmospheric research needs. The effort to develop WRF has been a partnership between the National Center for Atmospheric Research (NCAR), the National Oceanic and Atmospheric Administration (NOAA), the National Center for Environmental Prediction (NCEP), the Forecast Systems Laboratory (FSL), the Air Force Weather Agency (AFWA), the Naval Research Laboratory, the University of Oklahoma, and the Federal Aviation Administration (FAA). The model equations are solved for fully compressible and nonhydrostatic conditions. A detailed description can be found on the WRF web-site http://www.wrf-model.org/index.php. In addition 
Table 1. Information for the measurement of isoprene concentrations in the forests of the south of Shanghai during September 2009. The sampling duration is $30 \mathrm{~min}$.

\begin{tabular}{lrrrrrrrr}
\hline Date & Site & La & Lon & $\begin{array}{r}\text { Elev } \\
(\mathrm{m})\end{array}$ & $\begin{array}{r}\text { Time } \\
(\mathrm{LT})\end{array}$ & $\begin{array}{r}T \\
\left({ }^{\circ} \mathrm{C}\right)\end{array}$ & $\begin{array}{r}\text { Isop } \\
\text { Mea }\end{array}$ & $\begin{array}{r}\text { (ppbv) } \\
\text { Cal }\end{array}$ \\
\hline $09 / 04 / 09$ & 1 & 29.9370 & 120.8377 & 9 & $12: 00$ & 30 & 0.90 & 0.95 \\
$09 / 04 / 09$ & 2 & 29.5056 & 120.9085 & 75 & $14: 30$ & 28 & 3.42 & 2.30 \\
$09 / 04 / 09$ & 3 & 29.3826 & 120.4733 & 100 & $16: 00$ & 30 & 1.01 & 1.35 \\
$09 / 04 / 09$ & 4 & 28.9333 & 119.8413 & 90 & $15: 35$ & 29 & 2.01 & 1.76 \\
$09 / 05 / 09$ & 5 & 28.4264 & 119.9346 & 100 & $09: 00$ & 28 & 1.04 & 1.35 \\
$09 / 05 / 09$ & 6 & 28.3740 & 119.6055 & 135 & $10: 00$ & 28 & 2.16 & 2.07 \\
$09 / 05 / 09$ & 7 & 28.6052 & 119.3369 & 208 & $11: 00$ & 28 & 2.36 & 2.30 \\
$09 / 05 / 09$ & 8 & 28.8586 & 119.1975 & 171 & $12: 00$ & 34 & 5.14 & 3.15 \\
$09 / 05 / 09$ & 9 & 29.5619 & 119.4481 & 44 & $13: 20$ & 35 & 6.41 & 3.61 \\
$09 / 10 / 09$ & 10 & 30.7284 & 120.764 & 95 & $11: 00$ & 28 & 0.29 & 0.44 \\
\hline
\end{tabular}

to dynamical calculations, a chemical module (RAis coupled on-line with the WRF model. A detailed description of the chemical component of the model is given by Grell et al. (2005). The ozone formation chemistry is represented in the model by the RADM2 (Regional Acid Deposition Model, version 2) gas phase chemical mechanism (Chang et al., 1989) which includes 158 reactions among 36 species. The model is used here with some modifications introduced by Tie et al. $(2007,2010)$. The model was applied to study the regional distributions of $\mathrm{O}_{3}$ concentration in the Shanghai region. The model result was evaluated by comparing the calculated concentrations with the measured abundances, and the model evaluation suggested that the model is able to predict the large variability of ozone concentrations under different weather conditions in the Shanghai region (Tie et al., 2009).

In this study, the selected horizontal model resolution is $6 \mathrm{~km}$ in a $900 \times 900 \mathrm{~km}$ domain centered around Shanghai. The anthropogenic emission inventory for $\mathrm{SO}_{2}, \mathrm{CO}, \mathrm{NO}$, and VOCs is shown in Table 1 of Tie et al. (2009). In addition to the anthropogenic emissions, the biogenic emissions from vegetation are calculated in this model. The calculation of biogenic emission is particularly important, because this study focuses on the interaction between anthropogenic and biogenic emissions. Biogenic emissions in the model are generated by a biogenic emission module (MEGAN Model of Emissions of Gases and Aerosols from Nature) developed by Guenther et al. (2006). In this study, the MEGAN model is coupled with the WRF-Chem model for the online calculation of biogenic emissions, including isoprene $\left(\mathrm{C}_{5} \mathrm{H}_{8}\right)$. Two months of model calculations are performed in this study, i.e., July and September 2009. During September 2009, the concentrations of isoprene were measured in the forests located south of Shanghai. However, the prevailing winds during this month were mostly eastern winds. As a result, the biogenic emissions from the forests were not transported to the city of Shanghai. In order to study the interaction between anthropogenic and biogenic emissions and its effect on the ozone production in Shanghai, the model calculations were also made during July 2009. During this month, southern winds, suitable for the interaction study, frequently occurred.

\subsection{Data}

Ambient air samples were collected in the the field by pulling 21 of air onto a cartridge filled with Tenax GR and Carbograph 5TD using a mass flow controlled pump. Samples were either analyzed in the field within one day using a custom built thermal desorption system and a temperature programmed Inficon Hapsite portable Gas Chromatograph with Electron Impact Mass spectrometer (GC-MS) with a DB1 column or they transported to the NCAR Boulder, Colorado Laboratory and analyzed with a MARKES International Series 2 Ultra $^{\mathrm{TM}}$ TD autosampler coupled to a Unity 1 thermal desorption system interfaced with a temperature programmed Agilent 7890A Gas Chromatograph with a DB5 column and a 5975C Electron Impact Mass Spectrometer and a Flame Ionization Detector. For both field and laboratory analysis, cartridge samples were dried for $5 \mathrm{~min}$ with $30 \mathrm{sccm}$ UHP helium or nitrogen to remove adsorbed water before analysis. Isoprene was identified based on retention time of an authentic standard and comparison of mass spectra in the National Institute of Standards and Technologies (NIST) libraries. Quantification was based on comparison to a NIST certified standard. At each sampling site with a sampling time of $30 \mathrm{~min}$, air samples were collected onto two cartridges simultaneously, one for analysis in Shanghai using the Inficon GC-MS and one for analysis at NCAR using the Agilent GC-MS. Concentrations determined using the two analytical systems differed by an average of $18 \%$ with no systematic bias, and values reported are the average of the two determinations. Three blank (i.e., unfilled) cartridges were analyzed, yielding an average of $0.45 \mathrm{ng}$ of isoprene. Air samples ranged from 3.4 to $59 \mathrm{ng}$, averaging $24.6 \mathrm{ng}$, 
leading to a slight potential overestimation of air concentrations.

Routine measurements of air pollutants and meteorological parameters in Shanghai have been made since 2005 at 7 surface sites operated by Shanghai Meteorological $\mathrm{Bu}-$ reau (SMB). The measurements include $\mathrm{CO}, \mathrm{NO}, \mathrm{NO}_{2}, \mathrm{SO}_{2}$, $\mathrm{O}_{3}$, black carbon (BC), particulate matter $\left(\mathrm{PM}_{2.5}\right.$ and $\left.\mathrm{PM}_{10}\right)$, and solar radiation. The meteorological parameters include wind speed and direction, air temperature, humidity, and air pressure. In addition to the routine measurements, a comprehensive field experiment (MIRAGE-Shanghai; Megacities Impact on Regional and Global Environment at Shanghai) was conducted from 1 September to 21 September 2009. Participants in the experiment included SMB, National Center for Atmospheric Research (NCAR), Peking University, Fudan University, Texas A\&M University, and Institute of Earth Environment, Chinese Academy of Science. More chemical species were measured during the experiment, such as $\mathrm{NO}_{\mathrm{y}}, \mathrm{HONO}, \mathrm{HNO}_{3}$, and a more complete suite of $\mathrm{VOC}$, as well as aerosol composition and size distribution. Moreover, the isoprene concentrations were measured in the major forest region located south of Shanghai (see Fig. 1).

The focus of this research is to study the interaction between the biogenic emissions in major forests and the anthropogenic emissions in a megacity (Shanghai). For this purpose, the favorable conditions for this study need to be identified (i.e., the prevailing winds from the forests to Shanghai). As a result, the measurement of air pollutants $\left(\mathrm{O}_{3}, \mathrm{NO}_{\mathrm{x}}\right.$, etc) and meteorological parameters in two observation sites in Shanghai are analyzed. In this study, two measurement sites in the Shanghai region were selected, including (1) an urban-center site (PD) which is located in a commercial center of Shanghai, and (2) a rural site (CM) in the east-edge of the city which is located on an island surrounded by farmland. The detailed information regarding instrumentations and measurements was described by Geng et al. (2007).

\section{Result and analysis}

\subsection{Isoprene concentrations in the forests}

Figure 1 shows the emission rates of isoprene calculated by the MEGAN model in the Shanghai region. It indicates that to the south of Shanghai, there is large forest coverage, resulting in high emissions of isoprene. By contrast, to the north of Shanghai, the coverage of forests is limited and the isoprene emissions are small, and the spatial distribution of emissions is sparse. The measurement sites of isoprene in the forests are indicated in the white circles of Fig. 1. The detailed information concerning the measurements at these sites is given in Table 1. All measurements were made on 4 and 5 September, except sample 10, which was made on 10 September. The sampling time ranged from 09:00 to 15:00 local time, when the emission rates and

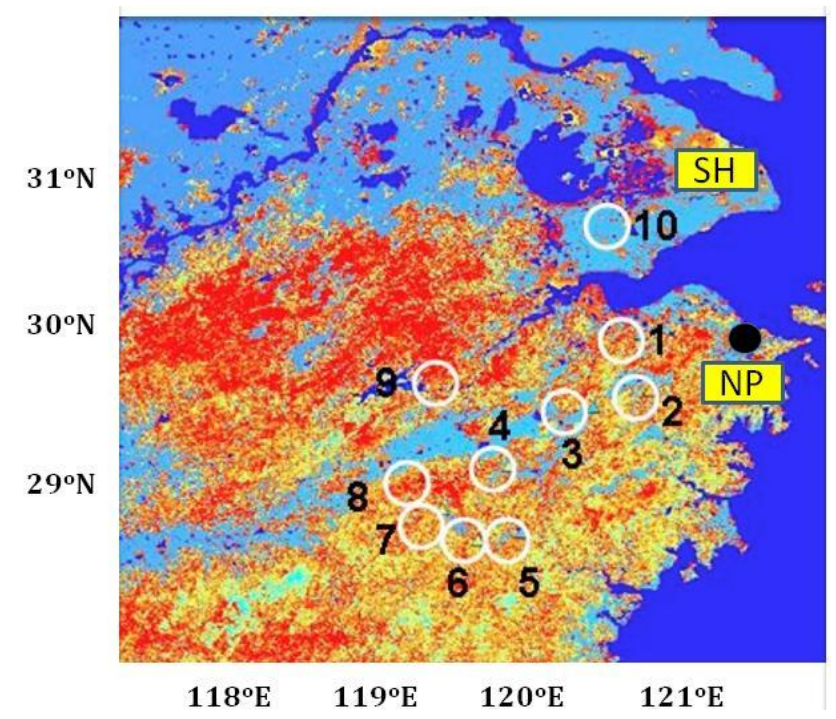

Fig. 1. MEGAN isoprene emission rates and measurement locations in the forests south of Shanghai.

ambient concentrations of isoprene are expected to be high (Guenther et al., 1995). Air temperatures were high, ranging from 28 to $35^{\circ} \mathrm{C}$, favorable for the production and release of isoprene from tree leaves (Guenther et al., 2000). The spatial distribution of the sampling locations suggests that the emission rates were high at all locations, except at site of sample 10. The highest emission rates were located in the sites of samples 8 and 9 .

In order to evaluate the model calculations, the predicted isoprene concentrations are compared with the measured values (shown in Fig. 2). The result indicates that calculated and measured isoprene concentrations are consistent with the emission rates indicated in Fig. 1. For example, the lowest concentration was measured in sample 10 (about $0.3 \mathrm{ppbv}$ ). The calculated value is also low in this sampling site (about $0.5 \mathrm{ppbv})$. For samples 2 to 7 , both the measured and calculated concentrations ranged from 1 to $3 \mathrm{ppbv}$, which indicates that the calculated isoprene concentrations are generally consistent with the measured values. For samples 8 and 9, the measured concentrations were highest (about 5 to $6 \mathrm{ppbv}$ ). These high concentrations mainly resulted from the high emission rates at the sampling sites (see Fig. 1). However, the calculated isoprene concentrations at these two sampling sites underestimated the measured isoprene concentrations. The calculated concentrations at these two sites range from 3.1 to $3.5 \mathrm{ppbv}$, which are lower than the measured values of 5.1 and 6.4 ppbv. One likely reason for the model underestimation is that the measurements were influenced by large amounts of bamboo vegetation at these two locations, which is a substantial source of isoprene (Geron et al., 2006). The landcover data currently available for estimating MEGAN isoprene emissions does not distinguish between bamboo and other broadleaf vegetation. The regional average broadleaf 


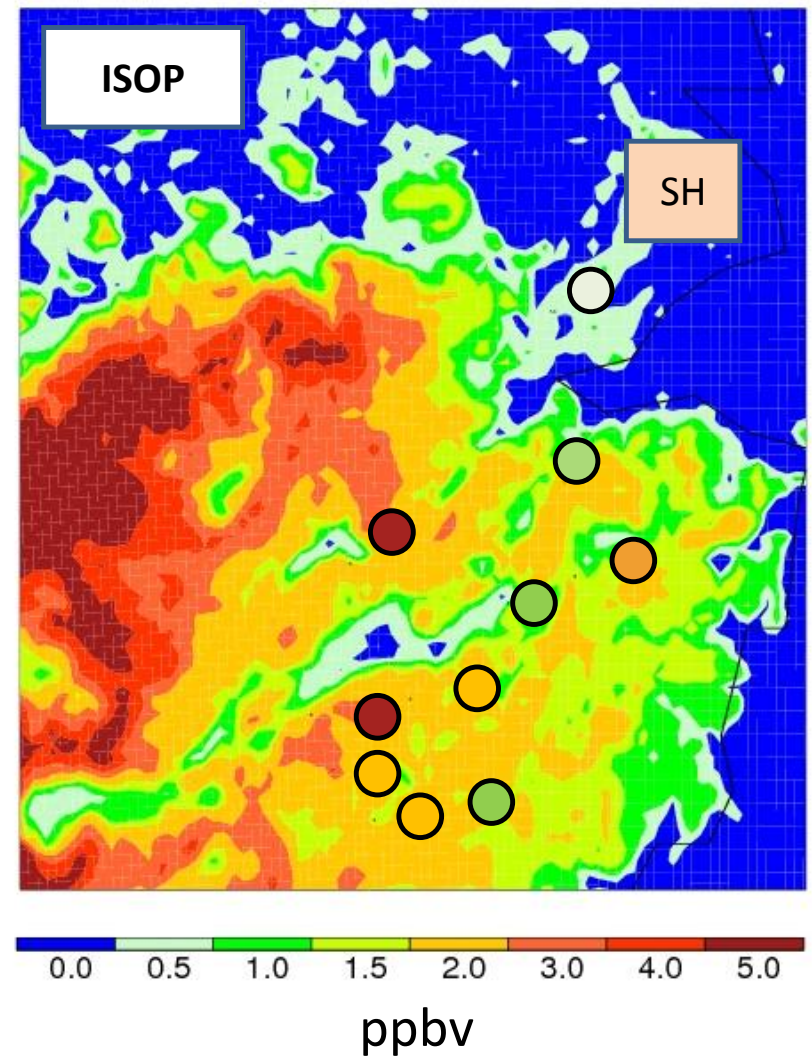

Fig. 2. Comparison of the calculated isoprene concentrations (ppbv) with the measured values (shown in the color filled circles). The measured values are averages obtained between 9:00 and 15:00 on 4 and 5 September 2009.

tree species composition is calculated for each province in China, using China forestry statistics, and assigned to all broadleaf trees and bamboo in the province. As a result, MEGAN underestimates the high isoprene emission from bamboo plantations. An improved landcover dataset that includes the spatial distribution of bamboo and other plantations is needed to improve MEGAN isoprene emission estimates for this region.

The calculated concentrations shown in Fig. 2 are averaged from 4 and 5 September, with the result that the comparison with the measurements only shows a rough correspondence (in an averaged condition). In order to precisely compare the model calculation with the measurement, a one by one comparison was made, in which calculations were made for those conditions prevailing at the time and location of each individual measurement (shown in Fig. 3). The result suggests that the calculated isoprene concentrations are well correlated with the measured values, with a correlation coefficient of 0.96 . However, the calculated values are lower than the measured values when the concentrations are above the 3 ppbv, indicating that the spatial distribution of bamboo plantations needs to be included in the landcover data used to drive MEGAN.

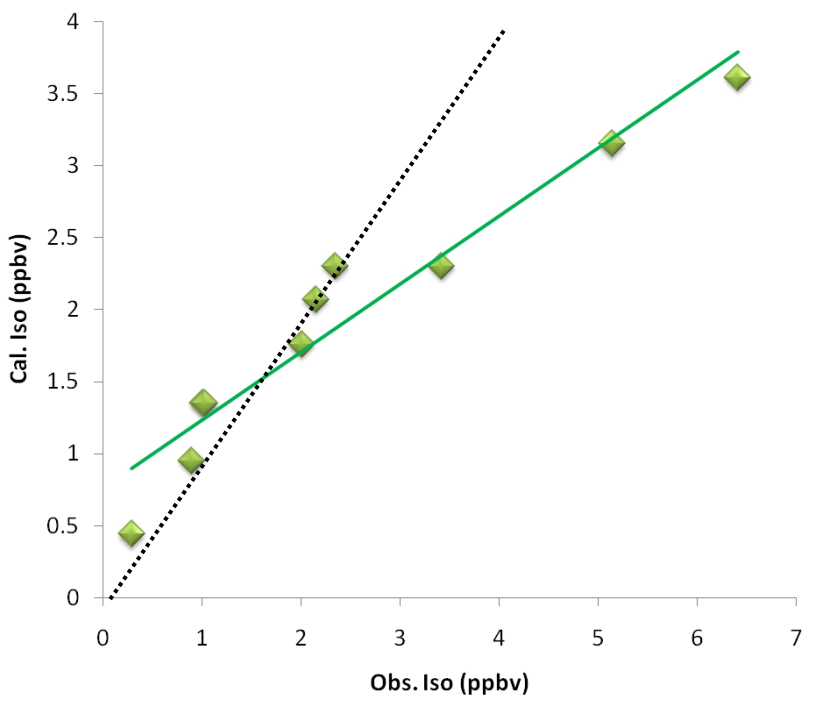

Fig. 3. One by one comparison of the calculated and measured isoprene concentrations. The green line is the fitting line of all the points, and the black dot line is the 1:1 line between the calculations and the measurements.

\subsection{The effect of isoprene in forests on ozone formation in Shanghai}

The formation of ozone in the troposphere is strongly dependent on the concentrations of nitrogen oxides $\left(\mathrm{NO}_{\mathrm{x}}\right)$ and volatile organic compounds (VOCs) (Sillman, 1995; Kleinman et al., 2000). Among VOCs, there are many different species, such as alkanes, alkenes, aromatics, etc. In the Shanghai region, anthropogenic emissions are major sources of VOCs, and propane and toluene are the most abundant, with averaged concentrations of 4.2 and 3.2 ppbv, respectively. The averaged total VOC concentration is about 32.4 ppbv (Geng et al., 2010; Cai et al., 2010). Total VOC concentrations in the forests south of Shanghai (a few ppbv) are much less than concentrations found in urban Shanghai, but the biogenic isoprene concentrations are comparable to the major individual anthropogenic VOC concentrations measured in the city. In addition to the concentrations of VOCs, the reactivity of VOCs (defined by the product of VOC concentration and $\mathrm{OH}$ reaction coefficient) is a crucial factor to determine the formation of ozone (Chameides et al., 1992). Because the reaction coefficient of $\mathrm{OH}$ with isoprene is the highest among all VOCs in the Shanghai region (Cai et al., 2010), the OH reactivity of isoprene is significantly higher than other VOCs. For example, the $\mathrm{OH}$ reactivities are $100,18,4.5\left(10^{-21} \mathrm{~cm}^{3} \mathrm{~s}^{-1}\right)$ for isoprene (assuming $1 \mathrm{ppbv}$ in the forests), toluene (3 ppbv in Shanghai), and propane (4 ppbv in Shanghai), respectively, indicating that isoprene has more potential than other major VOC species for the chemical formation of ozone. However, we must note that the high isoprene concentrations and thus the high $\mathrm{OH}$ 
reactivity of isoprene is not located in the city of Shanghai, but rather between 50 and several hundred $\mathrm{km}$ to the south of Shanghai. The main focus of this study is to investigate the effect of high $\mathrm{OH}$ reactivity of isoprene in the forests on the formation of $\mathrm{O}_{3}$ in the city of Shanghai.

As mentioned in the above sections, $\mathrm{NO}_{\mathrm{x}}$ is required for the formation of ozone in the forests. Figure 4 shows both the biogenic isoprene (calculated in MEGAN) and anthropogenic $\mathrm{NO}_{\mathrm{x}}$ (from emissions inventory) emissions in the Shanghai region. It shows a strong anti-correlation between the isoprene and $\mathrm{NO}_{\mathrm{x}}$ emissions in the region. In the major forest areas (mainly to the south of Shanghai), the emission rate of $\mathrm{NO}_{\mathrm{x}}$ is low, while in the urbanized areas (mainly in and to the north of Shanghai), the emission rate of isoprene is low. The anti-correlation between the areas of high $\mathrm{NO}_{\mathrm{x}}$ and high isoprene emissions suggests that the lack of $\mathrm{NO}_{\mathrm{x}}$ emissions in the forests may inhibit ozone production during the chemical process of the oxidation of isoprene.

Because the major forests are located south of Shanghai, winds from the south are required to transport the air containing biogenic emissions from the forests to the city. In some cases, the interaction between the air containing rich biogenic emissions (isoprene) from the forests and rich anthropogenic emissions from cities $\left(\mathrm{NO}_{\mathrm{x}}\right)$ can be mixed, which leads to favorable conditions for the chemical production of ozone. Figure 5 shows general meteorological and chemical conditions at the 2 stations (an urban site (PD) within the city) and a rural site (CM) on the eastern edge of the city during July 2009. The measured wind direction shows that between 10 and 18 July 2009, the wind directions were generally south or southwest winds. During this period, the air from the forests was transported to the city of Shanghai. The measured UV solar radiation suggests that there was no major reduction of UV, resulting in relatively high ozone concentrations, with the maximum ozone values of 60 to $110 \mathrm{ppbv}$. There were high wind speeds during this period. For example, the wind speeds were as high as $10 \mathrm{~m} \mathrm{~s}^{-1}$ in the rural site (CM). Because this site is close to the coast of Shanghai, the winds were not affected by the buildings in the city. As a result, the wind speeds are considerably higher than the winds in the urban site (PD). During the high wind period, the concentrations of $\mathrm{NO}_{\mathrm{x}}$ were generally low. However, on 12th and 15th, wind speeds were lower, resulting in higher $\mathrm{NO}_{\mathrm{x}}$ concentrations. These 2 days were selected for case studies, in which model simulations with (RUN-0) and without (RUN-1) biogenic isoprene emissions are conducted to study the impact of forest isoprene on the formation of ozone in the city of Shanghai.

Figure 6 shows the calculated changes in $\mathrm{O}_{3}$ concentrations due to isoprene emission from the forests by calculating the difference between RUN-0 and RUN-1 at noontime on 12 July 2009. The distribution of CO suggests that the air pollutants were transported northeastward in the Shanghai region, suggesting that the biogenic emissions from the forests could have an important impact on the chemical
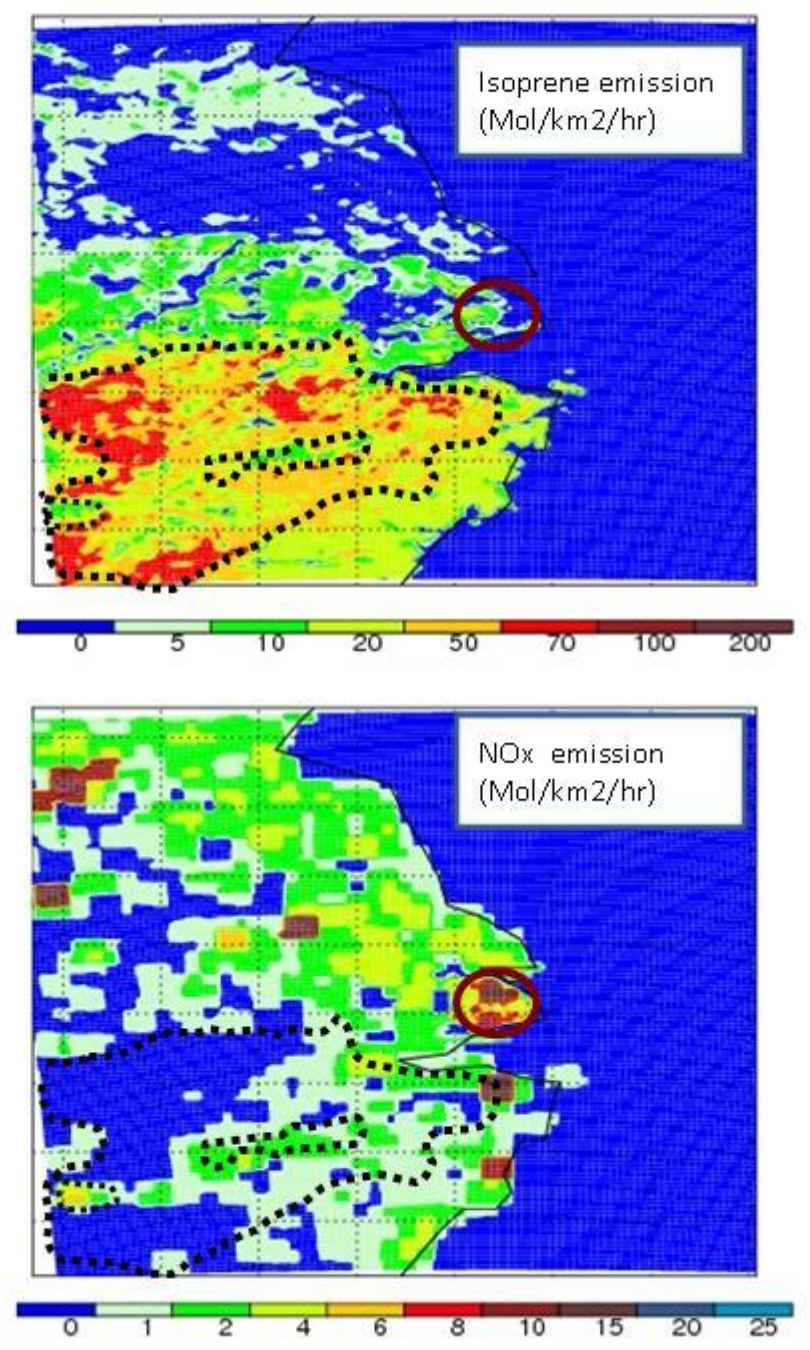

Fig. 4. Biogenic isoprene emissions in the forests calculated by the MEGAN model (upper panel), and anthropogenic $\mathrm{NO}_{\mathrm{x}}$ emissions based on the inventory in the WRF-Chem model (Tie et al., 2009). The dash-lines highlight the highest isoprene emission area.

production of ozone. The distribution of $\mathrm{NO}_{\mathrm{x}}$ indicates that high $\mathrm{NO}_{\mathrm{x}}$ concentrations (above $10 \mathrm{ppbv}$ ) were located north of the forests. However, in the forest area, the concentrations of $\mathrm{NO}_{\mathrm{x}}$ were generally low (less than $1 \mathrm{ppbv}$ ). We note that on the eastern edge of the forest areas, there were high $\mathrm{NO}_{\mathrm{x}}$ concentrations due to anthropogenic emissions of a large city (Ningpuo). Because this city is very close to the forests, there is a high impact on ozone formation around the city (see the detailed analysis below). Except for the area surrounding the city of Ningpuo, the distribution of isoprene shows that the high isoprene concentrations were limited to the forest areas and, due to its high reactivity and short chemical resident time (less than $1 \mathrm{~h}$ ), cannot be transported to the areas where the concentrations of $\mathrm{NO}_{\mathrm{x}}$ are high (north of the forests). This result suggests that the biogenic isoprene was confined 


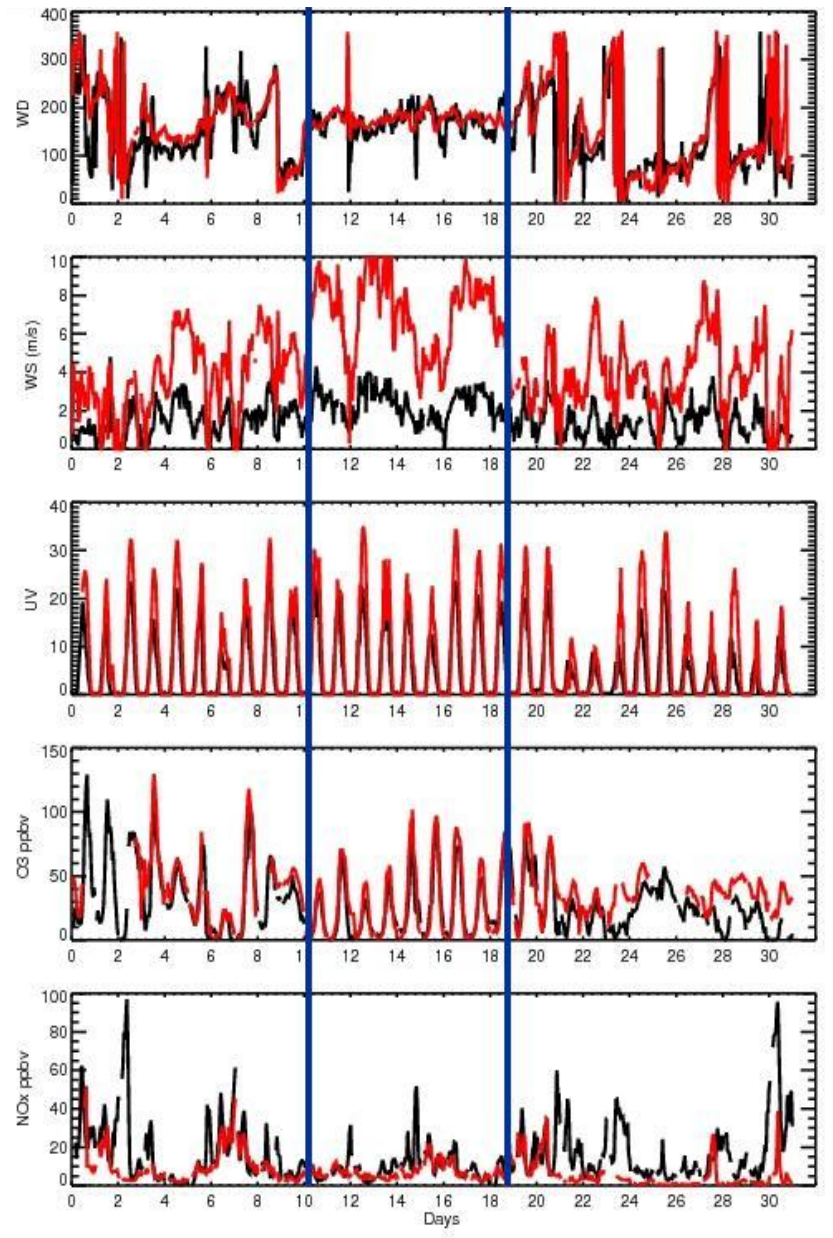

Fig. 5. General meteorological and chemical conditions at 2 stations (an urban site (PD) shown in black lines and a rural site (CM) shown in red lines) for wind direction, wind speed, $\mathrm{UV}, \mathrm{O}_{3}$, and $\mathrm{NO}_{\mathrm{x}}$ in Shanghai during July 2009. The blue lines indicate that between 10 and 18 July, 2009, the wind directions were generally from the south or southwest, and the air from the forests can be transported to the city of Shanghai.

to the locations of the emissions (the forests). Nevertheless, the distribution of ozone shows that the ozone concentrations were enhanced by the biogenic emissions of isoprene. However, the largest enhancement occurred not in the forest areas, but rather in the large cities downwind of the forests. There is thus an inconsistency between the enhancement of ozone production in the cities due to the biogenic emissions of the forests, and the fact that isoprene itself is not transported to the cities; this apparent contradiction is addressed in this study.

The above analysis clearly shows that there is a strong anticorrelation between biogenic isoprene and anthropogenic $\mathrm{NO}_{\mathrm{x}}$ in this region, and thus little interaction between air masses containing high concentrations of both compounds. How then do the biogenic emissions of isoprene affect the
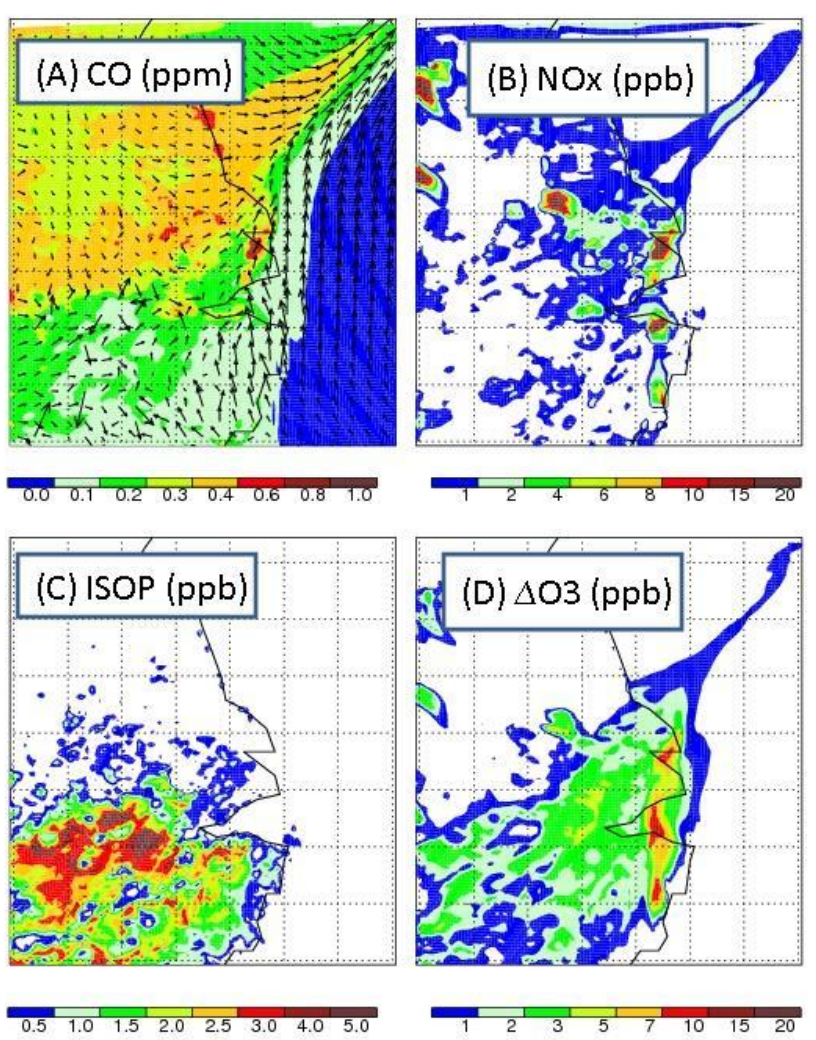

Fig. 6. The calculated $\mathrm{CO}, \mathrm{NO}_{\mathrm{x}}$, and isoprene concentrations at 12:00 p.m. of 12 July. (D) shows the calculated changes in $\mathrm{O}_{3}$ concentrations due to the forest isoprene emissions by calculating the difference between RUN-0 and RUN-1.

ozone formation in the areas downwind of the forests. To understand this question, we propose the following chemical mechanism as expressed in Fig. 7. According to the chemical mechanism of the WRF-Chem model, in the forests, isoprene is rapidly oxidized by $\mathrm{OH}$ radical to form peroxy radicals $\left(\mathrm{RO}_{2}\right)$ on a time scale of one hour. As indicated in Fig. 6, there are low $\mathrm{NO}_{\mathrm{x}}$ concentrations in the forest areas, which leads to relatively low ozone production in the forests. This mechanism is defined as the ozone production in the nearby isoprene source (black text in Fig. 7). However, the continued oxidation of isoprene and its products leads to the production of carbonyls, such as formaldehyde (HCHO) and acetaldehyde (ALD). The HCHO yield from isoprene oxidation on a per carbon basis is in the range of 0.3-0.45; it increases with $\mathrm{NO}_{\mathrm{x}}$ concentrations (Horowitz et al., 1998; Palmer et al., 2003). HCHO and ALD can further photo-dissociate to produce $\mathrm{HO}_{2}$ radicals. Because $\mathrm{HCHO}$ and ALD have longer chemical residence times (a few hours) than isoprene (Seinfeld and Pandis, 2006; Shim et al., 2005), they can be transported to regions downwind of the forests, such as the Shanghai city area. As a result, the $\mathrm{HO}_{2}$ radicals resulting from biogenic isoprene oxidation can be produced in the regions downwind of the forests, including the 


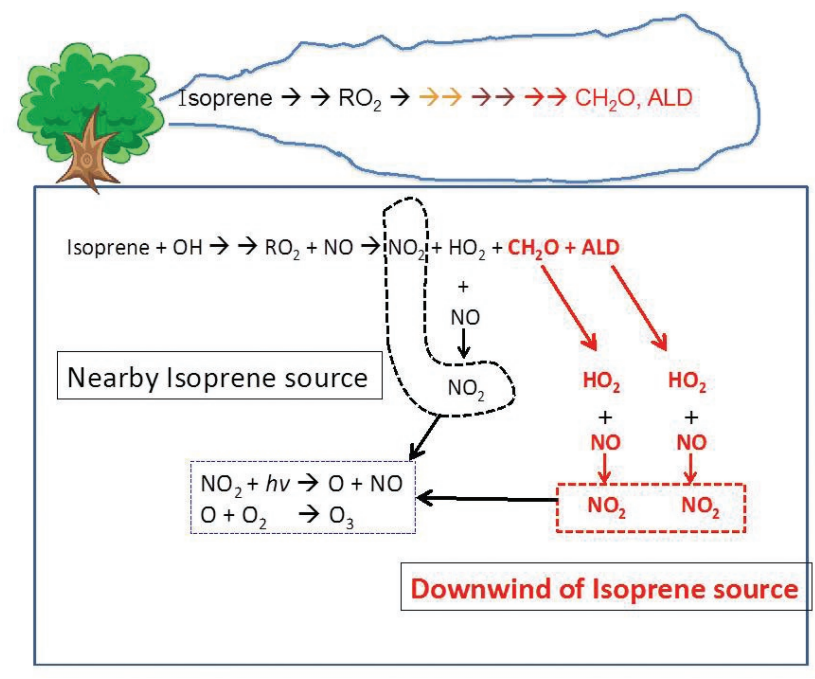

Fig. 7. Schematic picture illustrating the impact of biogenic emissions on the photochemical production of ozone in the forest source area and urban areas downwind of the forests.

Shanghai region, where the $\mathrm{NO}_{\mathrm{x}}$ concentrations are high, and conditions are favorable for ozone production. This mechanism is defined as the ozone production in the region downwind of the isoprene source in the forests (red text in Fig. 7).

Figure 8 shows the changes of $\mathrm{RO}_{2}$ due to the biogenic isoprene emissions in the forests at noontime on 12 July. It shows that the concentrations of $\mathrm{RO}_{2}$ were significantly enhanced due to the oxidation of isoprene, with a maximum of 30 ppt. However, the enhancement of $\mathrm{RO}_{2}$ is confined to the forests. As a result, the ozone production due to the oxidation of isoprene $\left(\mathrm{C}_{5} \mathrm{H}_{8}+\mathrm{OH} \rightarrow \rightarrow \mathrm{RO}_{2}+\mathrm{NO} \rightarrow \rightarrow \mathrm{O}_{3}\right)$ is mainly limited to the forest regions. We also note that the higher ozone production (Fig. 6) is not closely correlated with the higher $\mathrm{RO}_{2}$ concentration, but is more sensitive to the $\mathrm{NO}_{\mathrm{x}}$ concentrations. For example, in the east coast area, although there is a smaller enhancement of $\mathrm{RO}_{2}$, the higher $\mathrm{NO}_{\mathrm{x}}$ concentration in this region leads to higher ozone production than in the forest areas. The above analysis clearly indicates that the enhancement of ozone in the downwind regions (such as Shanghai) cannot be explained by the above chemical process (ozone production in nearby forest area).

As mentioned above, we hypothesize that the ozone production in regions downwind of the forests is attributed to the longer chemical resident time of carbonyls (such as HCHO and ALD) which are produced by a chain of reactions in the oxidation of isoprene. The main sinks of HCHO are photolysis and the reaction with atmospheric $\mathrm{OH}$, and its lifetime against oxidation is on the order of hours (Shim et al., 2005). The relatively longer chemical resident time of $\mathrm{HCHO}$ and ALD allows them to be transported to the downwind region of the forests, where they can be further photo-disassociated
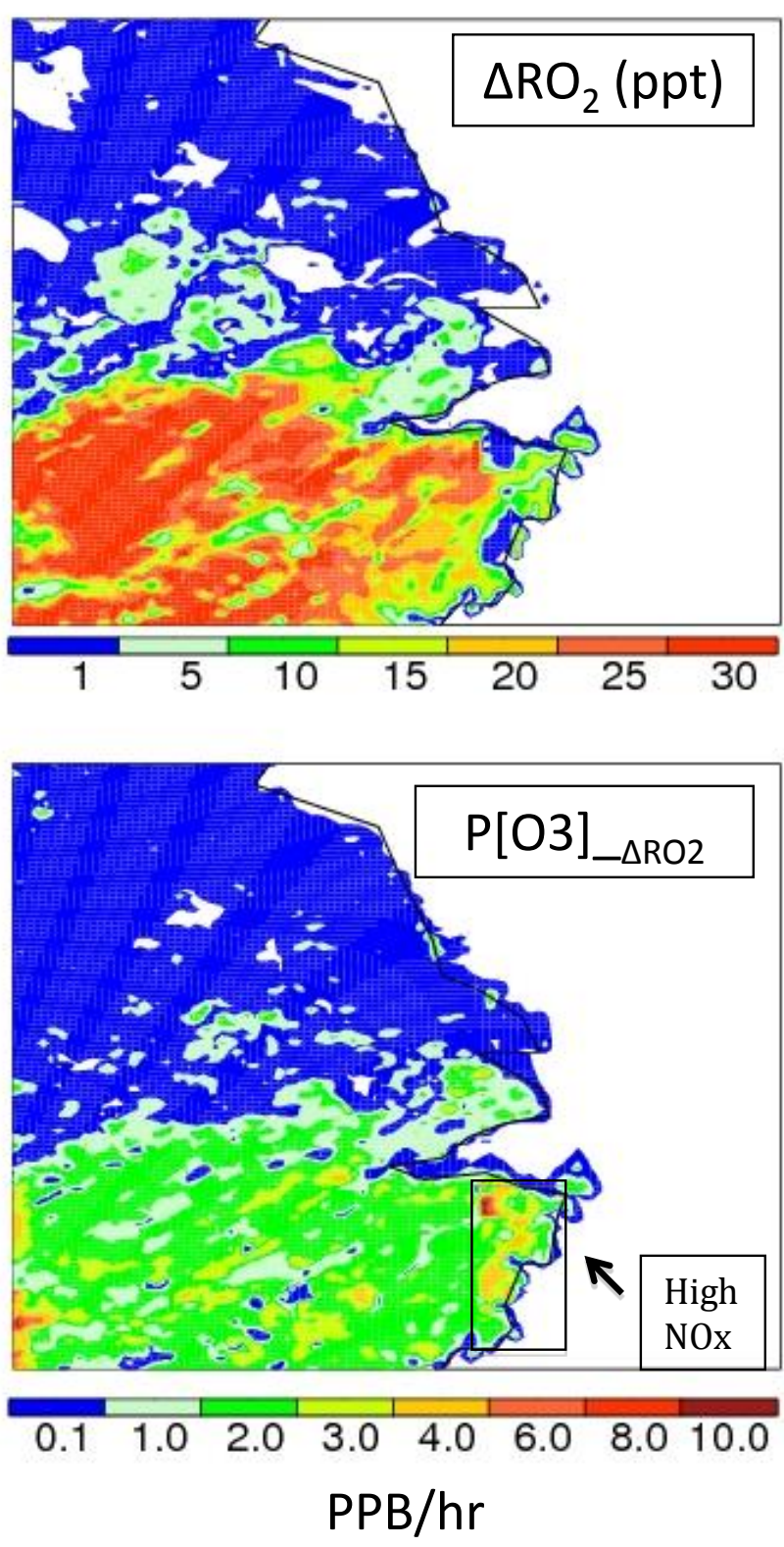

Fig. 8. Calculated increase of $\mathrm{RO}_{2}$ concentrations (ppt, in upper panel) and the rate of ozone production due to the enhancement of $\mathrm{RO}_{2}\left(\mathrm{ppbh}^{-1}\right.$, in lower panel) due to the biogenic emissions of isoprene in the forest areas at noontime of 12 July. The rectangle indicates the high $\mathrm{NO}_{\mathrm{x}}$ concentrations due to the anthropogenic emissions from large cities in the east coast regions.

to produce $\mathrm{HO}_{2}$ radicals. As indicated in Fig. 7, the $\mathrm{HO}_{2}$ radical reacts with $\mathrm{NO}$, leading to ozone production in the downwind regions. Figure 9 shows that the calculated concentrations of $\mathrm{HCHO}$ and ALD are enhanced in the downwind regions of the forests, with the maximum increase of 4$6 \mathrm{ppb}$. As a result, the concentrations of $\mathrm{HO}_{2}$ also increase in the same downwind areas, with an enhancement of 6-8 ppt. Because the concentrations of $\mathrm{NO}_{\mathrm{x}}$ in the downwind regions 

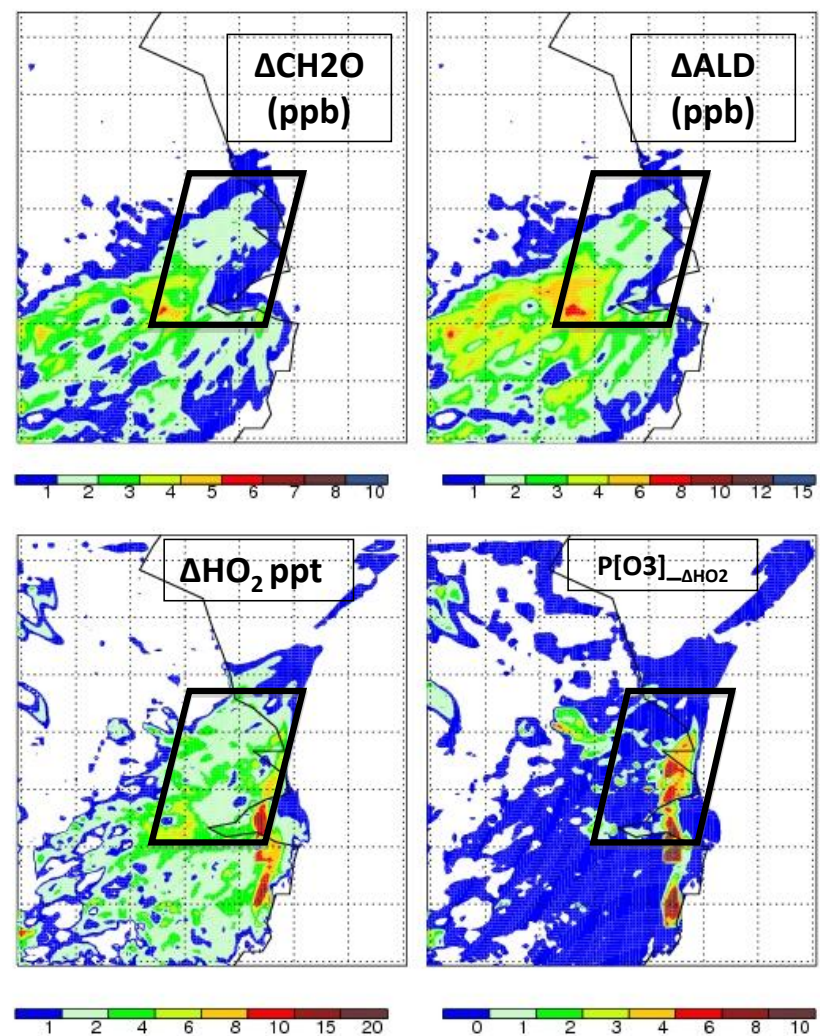

Fig. 9. Calculated increase of $\mathrm{CH}_{2} \mathrm{O}$ and $\mathrm{ALD}$ concentrations (ppb, in upper panel) and the enhancement of $\mathrm{HO}_{2}(\mathrm{ppt})$ due to the changes of $\mathrm{CH}_{2} \mathrm{O}$ and ALD as well as the rate of ozone production due to the enhancement of $\mathrm{HO}_{2}\left(\mathrm{ppbh}^{-1}\right.$, in lower panel) due to the biogenic emissions of isoprene in the forest areas at noontime of 12 July. The titled rectangle indicates the enhancement is located in the downwind of the forest emissions.

are considerably higher than the values in the forest areas (see Fig. 6), especially in the Shanghai city region, the reaction of $\mathrm{HO}_{2}+\mathrm{NO} \rightarrow \rightarrow \mathrm{O}_{3}$ leads to large increases in the chemical production of ozone. For example, the rate of ozone production is enhanced by $6-8 \mathrm{ppb} \mathrm{h}^{-1}$, which is higher than the enhancement $\left(2-3 \mathrm{ppb} \mathrm{h}^{-1}\right)$ due to the changes of $\mathrm{RO}_{2}$ by the oxidation of biogenic isoprene (see Fig. 8). This result is consistent with our hypothesis indicated in Fig. 7, showing the important effect of biogenic emissions on the ozone production in the urban areas downwind of the forests south of Shanghai. We also conducted a similar study for 15 July, when the winds were also from the south. The results (not shown) are similar to the result of 12 July.

\section{Summary}

It is well known that biogenic volatile organic compounds (BVOCs) from biogenic sources have important impacts on tropospheric chemistry, such as the formation of ozone. However, this interaction between biogenic and anthropogenic trace gases has strong regional characteristics, depending on the distributions of biogenic VOCs and anthropogenic $\mathrm{NO}_{\mathrm{x}}$ on regional scales. For this study, the Shanghai region, where the regional characteristics are particularly interesting, was selected. In the city of Shanghai, there are large $\mathrm{NO}_{\mathrm{x}}$ emissions, and the ozone production is strongly limited by VOC concentrations. To the south of Shanghai, there are major forest areas, where isoprene concentrations are high, but where $\mathrm{NO}_{\mathrm{x}}$ concentrations are low. Here the ozone production is limited by the levels of $\mathrm{NO}_{\mathrm{x}}$. The focus of this study is to assess the interaction between these two different regions (high $\mathrm{NO}_{\mathrm{x}}$ with low isoprene and low $\mathrm{NO}_{\mathrm{x}}$ and high isoprene). This study has important implications for other regions where forests are located close to urban areas.

In order to study the impact of biogenic isoprene on the ozone formation in the city of Shanghai, the concentrations of isoprene $\left(\mathrm{C}_{5} \mathrm{H}_{8}\right)$ were measured in the major forests located south of Shanghai, and a regional dynamical/chemical model (WRF-Chem) was applied for studying the effect of biogenic isoprene on the ozone production in Shanghai. Because there is a large coverage of isoprene-emitting broadleaved trees in this region, high concentrations of isoprene were measured, ranging from 1 to $6 \mathrm{ppbv}$. The evaluation of the model shows that isoprene concentrations calculated in the model agree with the measured concentrations when the measured isoprene concentrations are lower than $3 \mathrm{ppb}$, but underestimate the measurements when the measured values exceed $3 \mathrm{ppb}$. The underestimates occurred at sites near bamboo plantations, which are a strong source of isoprene, indicating the need to drive regional biogenic emissions models with landcover databases that can adequately represent the spatial distribution of bamboo and tree plantations. The assessment of the impact of isoprene on ozone formation suggests that there are two different mechanisms for ozone enhancement due to the oxidation of isoprene, which are defined by (a) ozone production in close proximity to isoprene sources, and (b) ozone production far downwind of isoprene sources. Near the isoprene sources, the concentrations of peroxy radicals $\left(\mathrm{RO}_{2}\right)$ are significantly enhanced due to the oxidation of isoprene by $\mathrm{OH}$, with a maximum of $30 \mathrm{ppt}$. However, the enhancement of $\mathrm{RO}_{2}$ is confined to the forest regions. Because the concentrations of $\mathrm{NO}_{\mathrm{x}}$ are low in the forest regions, the ozone production due to the oxidation of isoprene $\left(\mathrm{C}_{5} \mathrm{H}_{8}+\mathrm{OH} \rightarrow \rightarrow \mathrm{RO}_{2}+\mathrm{NO} \rightarrow \rightarrow \mathrm{O}_{3}\right)$ is low (less than 2-3 $\mathrm{ppb} \mathrm{h}^{-1}$ ). By contrast, downwind of isoprene sources, longer-lived carbonyls such as formaldehyde and acetaldehyde are significantly enhanced, due to continuous oxidation of isoprene in the forest air. As a result, the concentrations of $\mathrm{HO}_{2}$ radical are increased, resulting from the photo-disassociation of formaldehyde and acetaldehyde. Because the enhancement of $\mathrm{HO}_{2}$ radical occurs downwind of the forests (such as in the city of Shanghai), the concentrations of $\mathrm{NO}_{\mathrm{x}}$ are significantly higher than the values in the forests, leading to an enhancement of ozone production (6$\left.8 \mathrm{pph} \mathrm{h}^{-1}\right)$. We should note that in different cities and forest 
areas, this kind study should be also conducted due to the fact that NOx and isoprene emissions vary in different regions. This study suggests that the biogenic emissions in the major forests south of Shanghai have important impacts on the levels of ozone in the city, mainly due to the production and transport of carbonyls produced by the continuous oxidation of isoprene in the forest air.

Acknowledgements. This work is funded by the National Natural Science Foundation of China (NSFC) under Grant No. 40705046; The Shanghai Science and Technology commission under Grand No. 08230705200; The Chinese Ministry of Finance Research Program under Grand No. GYHY(QX)20070619. The National Center for Atmospheric Research is sponsored by the National Science Foundation.

Edited by: C. H. Song

\section{References}

Cai, C. J., Geng, F. H., Tie, X., Yu, X. Q., and An, J. L.: Characteristics and source apportionment of VOCs measured in Shanghai, China, Atmos. Environ. 44,5005-5014, doi:10.1016/j.atmosenv.2008.05.045, 2010.

Carlo, P. D., Brune, W. H., Martinez, M., Harder, H., Lesher, R., Ren X., Thornberry, T., Carroll, M. A., Yong, V. Shepson, P. B., Riemer, D., Apel, E., and Campbell, C.: Missing OH Reactivity in a Forest: Evidence for Unknown Reactive Biogenic VOCs, Science, 304, 722-725, doi:10.1126/science.1094392, 2004.

Carslaw, N., Bell, N., Lewis, A. C., McQuaid, J. B., and Pilling, M. J.: A detailed case study of isoprene chemistry during the EASE96 Mace Head campaign, Atmos. Environ., 34, 28272836, 2000.

Chameides, W. L., Lindsay, R. W., Richardson, J., and Kiang, C. S.: The role of biogenic hydrocarbons in urban photochemical urban photochemical smog - Atlanta as a case-study, Science, 241, 1473-1475, 1988.

Chameides, W. L., Fehsenfeld, F., Rodgers, M. O., Cardelino, C., Martines, J., Parrish, D., Lonneman, W., Lawson, D. R., Rasmussen, R. A., Zimmerman, P., Greenberg, J., Middleton, P., and Wang, T.: Ozone precursor relationships in the ambient atmosphere, J. Geophys. Res., 97, 6037-6055, 1992.

Chang, J. S., Binkowski, F. S., Seaman, N. L., McHenry, J. N., Samson, P. J., Stockwell, W. R., Walcek, C. J., Madronich, S., Middleton, P. B., Pleim, J. E., and Lansford, H. H.: The regional acid deposition model and engineering model, State-ofScience/Technology, Report 4, National Acid Precipitation Assessment Program, Washington DC, 1989.

Farina, S. C., Adams, P. J., and Pandis, S. N.: Modeling global secondary organic aerosol formation and processing with the volatility basis set: implications for anthropogenic secondary organic aerosol, J. Geophys. Res., 115, D09202, doi:10.1029/2009JD013046, 2010.

Fehsenfeld, F., Calvert, J., Fall, R., Goldan, P., Guenther, A. B., Hewitt, Lamb, B., Liu, S., Trainer, M., Westberg, H., and Zimmerman, P.: Emissions of volatile organic compounds from vegetation and the implications for atmospheric chemistry, Global Biogeochem. Cy., 6, 389-430, doi:10.1029/92GB02125, 1992.
Geng, F. H., Zhao, C. S., Tang, X., Lu, G. L., and Tie, X.: Analysis of ozone and VOCs measured in Shanghai: A case study, Atmos. Environ., 41, 989-1001, 2007.

Geng, F. H., Qiang, Z., Tie, X., Huang, M., Ma, X., Deng, Z., Quan, J., and Zhao, C.: Aircraft measurements of $\mathrm{O}_{3}, \mathrm{NO}_{\mathrm{x}}, \mathrm{CO}$, VOCs, and $\mathrm{SO}_{2}$ in the Yangtze River Delta region, Atmos. Environ., 43, 584-593, 2009.

Geng, F. H., Cai, C. G., Tie, X., Yu, Q., An, J. L., Peng, L., Zhou, G. Q., and Xu, J. M.: Analysis of VOC emissions using PCA/APCS receptor model at city of Shanghai, China, J. Atmos. Chem., 62, 229-247, doi:10.1007/s10874-010-9150-5, 2010.

Grell, G. A., Peckham, S. E., Schmitz, R., McKeen, S. A., Wilczak, J. and Eder, B.: Fully coupled "online" chemistry within the WRF model, Atmos. Environ., 39, 6957-6975, 2005.

Guenther, A., Hewitt, N., Erickson, D., Fall, R., Geron, C., Graedel, T., Harley, P., Klinger, L. Lerdau, M., McKay, W. A., Pierce, T., Scholes, B., Steinbrecher, R., Tallamraju, R., Taylor, J., and Zimmerman P.: A global model of natural volatile organic compound emissions, J. Geophys. Res., 100, 8873-8892, 1995.

Guenther, A., Geron, C., Pierce, T., Lamb, B., Harley, P. and Fall, R.: Natural emissions of non-methane volatile organic compounds; carbon monoxide, and oxides of nitrogen from North America, Atmos. Environ., 34, 2205-2230, 2000.

Guenther, A., Karl, T., Harley, P., Wiedinmyer, C., Palmer, P. I., and Geron, C.: Estimates of global terrestrial isoprene emissions using MEGAN (Model of Emissions of Gases and Aerosols from Nature), Atmos. Chem. Phys., 6, 3181-3210, doi:10.5194/acp-63181-2006, 2006.

Horowitz, L. W., Liang, J., Gardner, G. M., and Jacob, D. J.: Export of reactive nitrogen from North America during summertime: Sensitivity to hydrocarbon chemistry, J. Geophys. Res., 103, 13451-13476, 1998.

Jacob, D., Field, B. D., Li, Q., Blake, D. R., de Gouw, J., Warneke, C., Hansel, A., Wisthaler, A., Singh, H. B., and Guenther, A.: Global budget of methanol: Constraints from atmospheric observations, J. Geophys. Res., 110, D08303, doi:10.1029/2004JD005172, 2005.

Kleinman, L. I., Daum, P. H., Imre, D. G., Lee, J. H., Lee, Y.-N., Nunnermacker, L. J., Springston, S. R., WeinsteinLloyd, J., and Newman, L.: Ozone production in the New York City urban plume, J. Geophys. Res., 105, 14495-14512, doi:10.1029/2000JD900011, 2000.

Lack, D., Tie, X., Neville, A., Bofinger, D., Wiegand, N., Aumont, B., and Madronich, S.: Seasonal variability of atmospheric oxidants due to the formation of secondary organic aerosol: A global modeling study, J. Geophys. Res., 108, D03203, doi:10.1029/2003JD003418, 2004.

Lathière, J., Hauglustaine, D. A., Friend, A. D., De NobletDucoudré, N., Viovy, N., and Folberth, G. A.: Impact of climate variability and land use changes on global biogenic volatile organic compound emissions, Atmos. Chem. Phys., 6, 2129-2146, doi:10.5194/acp-6-2129-2006, 2006.

Li, G., Zhang, R., Fan, J., and Tie, X.: Impacts of biogenic emissions on photochemical ozone formation in Houston, Texas, J. Geophys. Res., 112, D10309, doi:10.1029/2006JD007924, 2007.

Pierce, T., Geron, C., Bender, L., Dennis, R., Tonnesen, G., and Guenther, A.: Influence of increased isoprene emissions on regional ozone modeling, J. Geophys. Res., 103, 25611-25629, 1998. 
Roselle, S.: Effects of biogenic emission uncertainties on regional photochemical modeling of control strategies, Atmos. Environ., 28, 1757-1772, 2000.

Seinfeld, J. H. and Pandis, S. N.: Atmospheric Chemistry and Physics: From Air Pollution to Climate Change, 2nd Edn., John Wiley and Sons, New York, 2006.

Shanghai Municipal Statistics Bureau (SMSB): Shanghai Statistical Yearbook; China Statistical Press: China, 2009

Shim, C., Wang, Y., Choi, Y., Palmer, P. I., Abbot, D. S., and Chance, K.: Constraining global isoprene emissions with Global Ozone Monitoring Experiment (GOME) formaldehyde column measurements, J. Geophys. Res., 110, D24301, doi:10.1029/2004JD005629, 2005.

Sillman, S.: The use of $\mathrm{NO}_{y}, \mathrm{H}_{2} \mathrm{O}_{2}$, and $\mathrm{HNO}_{3}$ as indicators for ozone- $\mathrm{NO}_{\mathrm{x}}$-hydrocarbon sensitivity in urban locations, J. Geophys. Res., 100, 14175-14188, 1995.

Tie, X., Guenther, A., and Holland, E.: Biogenic methanol and its impact on tropospheric oxidants, Geophys. Res. Lett., 30, 1881, doi:10.1029/2003GL017167, 2003.

Tie, X., Li, G., Ying, Z., Guenther, A., and Madronich, S.: Biogenic emissions of VOCs and NO in China and Comparison to Anthropogenic Emissions, Sci. Total Environ., 371, 238-251, 2006.
Tie, X., Madronich, S., Li, G. H., Ying, Z. M., Zhang, R., Garcia, A., Lee-Taylor, J., and Liu, Y.: Characterizations of Chemical Oxidants in Mexico City: A Regional Chemical/dynamical Model (WRF-Chem) Study, Atmos. Environ., 41, 1989-2008, 2007.

Tie, X., Geng, F. H., Peng, L., Gao, W., and Zhao, C. S.: Measurement and modeling of $\mathrm{O}_{3}$ variability in Shanghai, China; Application of the WRF-Chem model, Atmos. Environ., 43, 42894302, 2009.

Tie, X., Brasseur, G., and Ying, Z.: Impact of model resolution on chemical ozone formation in Mexico City: application of the WRF-Chem model, Atmos. Chem. Phys., 10, 8983-8995, doi:10.5194/acp-10-8983-2010, 2010.

Volkamer, R., Jimenez, J. L., San Martini, F., Dzepina, K., Zhang, Q., Salcedo, D., Molina, L. T., Worsnop, D. R., and Molina, M. J.: Secondary organic aerosol formation from anthropogenic air pollution: Rapid and higher than expected, Geophys. Res. Lett., 33, L17811, doi:10.1029/2006GL026899, 2006.

Wiedinmyer, C., Tie, X., Guenther, A.: Changes in biogenic volatile organic emissions that occur as a result of land cover change: How do they affect regional and global atmospheric chemistry?, Earth Interact., 10, 1-19, 2006. 